\title{
5 Knowledge about Roma and Travellers in Nordic schools
}

\author{
Paradoxes, constraints, and possibilities ${ }^{1}$
}

\author{
Jenni Helakorpi
}

\section{Introduction}

Roma and Travellers (resande/romanifolk/tatere) ${ }^{2}$ are national minorities in Finland, Sweden, and Norway. Although education systems purport to treat everybody equally, surveys indicate that students who identify as Roma or Travellers have distinctive educational experiences, paths, and outcomes. According to national surveys, Roma and Traveller pupils are at greater risk than their peers of dropping out of basic education (i.e. comprehensive school), and of not continuing to upper secondary education (AoI 2009; MSAH 2009; NOU 2015; SOU 2010). Furthermore, Roma and Traveller pupils are subjected to prejudice, racism, and bullying in schools (Junkala and Tawah 2009; NOU 2015; Rajala et al. 2011; Rajala and Blomerus 2015; SOU 2010). Finland, Sweden, and Norway have acknowledged the inequities in the educational outcomes of Roma and Traveller pupils and have introduced policies and practices to improve the educational situation. As one key measure, policies, and practices that promote the provision of knowledge about Roma and Travellers for the school communities have been recommended by different agencies (Helakorpi, Lappalainen, and Mietola 2018).

Providing knowledge about minoritised groups is a widespread measure in educational policies and practices aimed at promoting equality (Gorski 2006, 2016; Kumashiro 2002). In my view, the measure can be characterised as a "traveling discourse" in education (Lahelma 2005; Lindblad and Popkewitz 2003), which can be found in various contexts globally. The provision of knowledge about minoritised groups usually aims to diversify school curricula and lessons by including knowledge about different groups, and to counter stereotypes and false information. These measures are based on the assumptions that information about minoritised groups evokes feelings of empathy within pupils who occupy privileged positions, and that this empathy leads to changes in schools and societies (Kumashiro 2002). Kevin Kumashiro (2002), however, warns that although well intended, such practices may enhance the processes of Othering. Like Kumashiro, Paul C. Gorski (2006, p. 165) claims that rather than simply providing knowledge about minoritised groups, the promotion of justice in education would call for institutional transformation 


\section{Helakorpi}

with "a continual analysis of institutional power and privilege" (see also hooks 1994). Nevertheless, current policies promote increased knowledge about Roma and Travellers in schools in Finland, Sweden, and Norway, and the individuals working to promote the education of these groups are expected to provide it (see also Helakorpi, Lappalainen, and Sahlström 2019; Helakorpi et al. 2018).

Drawing from feminist post-structural theories in education (e.g. Davies 2004; St. Pierre and Pillow 2000; St. Pierre 2000), this chapter sets out to investigate the ways in which 18 interviewees-who identify as Roma or Travellers, and who work to promote the basic education of these groups - make sense of the practice of "provision of knowledge about Roma and Travellers"; giving lectures about Roma and Travellers was one of the practices the research participants were developing and establishing to improve the basic education of the groups. In the interviews, the research participants describe why and how they provide knowledge about the groups, and what they understand the tenets of that knowledge to be. Drawing from Bronwyn Davies (2004, pp. 4-5) I understand the descriptions of the practice from a post-structural (Foucauldian) viewpoint as indicating "the ways sense is being made", and the ways in which this making sense becomes possible within available discourses (Davies 2004, pp. 4-5; St. Pierre 2000).

This data does not provide possibilities to make systematic comparisons between nation-states. However, in this chapter, the practices aimed at promoting the basic education of Roma and Travellers are understood as "analogical incidents" which are analysed "in various cultural contexts" (Lappalainen, Lahelma, and Mietola 2015, pp. 845-846). The practices are perceived as analogical because they are emerging in the intersections of similar kinds of national policy processes, which are entangled in supranational policy processes: the internationalisation of Roma and Traveller policies, minority policies, and education policies (Brubaker 1996; Kymlicka 2007; Vermeersch 2006; see also Helakorpi, Lappalainen, and Mietola 2018). Furthermore, the three countries have historically co-operated and are currently co-operating in Roma and Traveller policies, and the policies are intertwined historically and currently (Pulma 2006; AoI 2009; MSAH 2016; SOU 2009). The ways the interviewees make sense of their practices are constituted in relation to "networks and supranational authorities and organisations [...] who mobilise particular ways of reasoning about and engaging in educational matters" (Lindbald and Popkewitz 2003 p. 11). Although the contexts differ, the interest of the analysis lies in cross-cultural patterns.

\section{Diverse groups categorised and controlled}

The umbrella term 'Roma and Travellers', or often just 'Roma', covers multiple Roma and Traveller groups; Roma and Travellers, however, have varying perceptions of the use of the transnational identity of 'Roma and Travellers' (Bunescu 2014; CoE 2012). The groups have been persecuted and racism ${ }^{3}$ 
against them is still commonplace and systematic (Brearley 2001; Hancock 1989; Izsák 2015; FRA 2018). Today, international governmental organisations pay special attention to Roma and Travellers as a distinctive transnational group, and Roma and Traveller groups have been defined as national minorities in many European countries (see e.g. Vermeersch 2006; van Baar 2012).

This chapter discusses policies and practices targeted at those Roma and Traveller groups who have national minority status in Finland, Sweden, and Norway. In Finland, the national Roma minority includes one Roma group: Finnish Roma/Kale. It is estimated that today there are approximately 9,000 to 10,000 Finnish Roma in Finland (Rajala and Blomerus 2015) ${ }^{4}$. In Sweden, the national Roma minority includes several Roma groups, which are usually described by the period of their arrival in Sweden: Travellers (resande), Swedish Roma, Finnish Roma/Kale, Non-Nordic Roma, and recently-arrived Roma. These groups contain multiple subgroups. It has been estimated that there are around 50,000 people who identify as Roma (or Traveller) in Sweden (SOU 2010). In Norway, two different national minority Roma groups have been defined: Roma (rom) and Travellers (romanifolk/tatere). It is estimated that there are around 700 Norwegian Roma, and around 4,000 to 10,000 Norwegian Travellers in Norway (Engebrigtsen 2015; Muižnieks 2015).

Current policy categories have diverse and somewhat messy and disputed trajectories. The early history of the emergence of the policy categories is interconnected in all three countries: the first literary notes about Roma in the Nordic countries are from the early sixteenth century. Terms tattare/tatere were adopted from the German language to refer to a group of people in the Nordic region, who the officials believed to share the same origin (Pulma 2006; Montesino Parra 2002; Rekola 2012). However, the use of these categories was ambiguous, and varied between regions (Rekola 2012). Especially in territories which are today (parts of) Norway and Sweden, the category was also used to refer to various local and foreign itinerant groups, who the states wanted to control (Pulma 2006). The current Norwegian national minority category Travellers (romanifolk/tatere) originates from here. When Norway defined its national minorities, some Norwegian Travellers contested the idea of becoming a national minority and considered the categorisation to be yet another stigmatising practice, and a way to introduce targeted disciplinary measures (St. Meld 2000, p. 46). The national minority Norwegian Roma (rom) refers to Roma who migrated to Norway during the $1800 \mathrm{~s}$.

In Sweden, the term tattare became interchangeable with the term zigenare. However, in the late nineteenth century (when Finland was already part of the Russian empire), these ambiguous terms became separated to refer to different groups. The distinction served to make a difference between the nationstate's "own" tattare and the later migrated "foreign" zigenare (Montesino Parra 2002, 96). In the 1950s, the category of zigenare was also divided into categories of "Swedish" and "foreign", when new groups of Roma migrated to Sweden and were categorised as "foreign". Later, the Roma category splintered even further when new Roma migrated to Sweden (Montesino 


\section{Helakorpi}

Parra 2002). Although the diversity of Roma and Traveller groups in Sweden is apparent, the Swedish national minority politics treats Swedish Roma and Travellers as one diverse group called Roma (romer), and they are targeted by the same policy processes (SOU 2010). The process of defining the Swedish national minorities was not straightforward, and for instance, some Swedish Travellers have contested being grouped together with Roma (Wiklander 2015).

After Finland became the Finnish Grand Duchy of the Russian empire in the early nineteenth century, the policy category Roma (mustalainen/zigenare), which originates from the time Finland was part of Sweden, became quite clear-cut: current research indicates that there were no other itinerant groups in Finland other than Finnish Roma, who now hold a national minority position (Pulma 2006, 48).

The diverse ethnic groupings and identities of Roma and Travellers in the Nordic countries have emerged as a result of complex historical movements and interactions between different people throughout the centuries. Furthermore, these groupings - and the living conditions of people who identify or have identified as part of these groups - have been shaped by nation-state building, scientific racism, different periods of Roma and Traveller politics, and legislation concerning, for example, poverty, vagrancy, and migration (see e.g. Tervonen 2012; Pulma 2006; Montesino Parra 2002). These groups have been marginalised: each group has been subjected to either or both assimilation and/or exclusion in Finland, Sweden, and Norway, based on (racialising) representations maintained in public discourses.

The turn in political discourses from exclusion and assimilation, towards human and cultural rights, is recent. Even after the Second World War, policy programmes for Finnish Roma in Finland included practices such as children's homes which aimed to "normalise" the Roma and assimilate them (Friman-Korpela 2014; Pulma 2006). Furthermore, during the period from 1950 to 1970 (the second phase of Finnish sterilisation politics), the Finnish state's social welfare policies enabled doctors and social workers, amongst others, to subject Roma to sterilisations (Mattila 2005). Sterilisations also took place in Sweden until the mid-1970s, and were directed to some extent towards Roma and Travellers (SOU 2000; Vitbok 2014). Furthermore, many Roma in Sweden were without residence until the 1960s and did not have access to general welfare services (Vitbok 2014). In Norway, sterilisation policies which remained until 1977 likewise included Travellers (NOU 2015). Moreover, as in Finland, Traveller children were removed from their families and placed in children's homes, while adults were made to work in Traveller labour colonies. The aims of these practices were to teach Travellers "the Norwegian" lifestyle, to get them to settle down, and to erode Traveller culture and language. The last of the labour colonies was closed in 1989 (NOU 2015). Most of the Norwegian Roma were caught and sent to Nazi extermination camps during the Second World War, since Norway forbade their return to Norway in 1934 (Pulma 2006; Rosvoll and Bielenberg 2012). The surviving Norwegian Roma were not allowed to re-enter Norway until 1956. 
Until the early 1970s, the authorities tried to prevent Roma from coming and settling in Norway (Pulma 2006).

Although the current political discourse today stresses the human and cultural rights of Roma and Travellers, multiple forms of racism and discrimination against Roma and Travellers are widely spread in these societies (e.g. Keskinen et al. 2018; Non-discrimination Ombudsman 2014; NOU 2015; Rosvoll and Bielenberg 2012; SOU 2016).

\section{Data and analysis}

Today, Finland, Sweden, and Norway have policy processes which promote the basic education of national Roma and/or Traveller minorities (see Helakorpi, Lappalainen and Mietola 2018), and for this research, I wanted to reach persons who implement these policies locally. I approached interviewees through networks, organisations, and municipalities, and the data for this chapter includes interviews with 18 individuals who identify as Roma or Traveller, and work to promote the basic education of national Roma and/or Traveller minorities.

Seven of the interviewees are from Finland. They worked or had worked as Roma mediators in schools. The Finnish interviews were conducted in Finnish in multiple municipalities. Eight of the interviews were conducted in Sweden, in several municipalities, in Swedish or English. Four of the Swedish interviewees worked as Roma mediators in schools, and four worked in administration, where developing basic education of Roma children was one part of their work. Also included in the data are three interviews from Norway from one municipality: two of the interviewees identify as Norwegian Travellers (interviewed together), and one identifies as Norwegian Roma. The Norwegian interviewees were activists or working for NGOs, and they were developing practices for schools and other institutions. The Norwegian interviews were conducted mainly in Swedish, but partly in Norwegian and English. The interviews were semi-structured, and all the interviews, except for one, ${ }^{5}$ were recorded and transcribed. Since the interviewees could be easy to identify, the work of the interviewees is not described in detail, and personal information, such as age and gender, is concealed.

The interviewees hold varying employment positions. The Norwegian interviews in particular differ from their Finnish and Swedish counterparts, since the interviewees were not working for municipalities or governments. This was due to the different Roma/Traveller policy landscape in Norway: municipal and government employees were not Roma or Travellers, and the Roma and Traveller representatives in the field are, for example, activists or representatives of NGOs. In Sweden and Finland, a significant number of employees working with Roma issues identified as Roma. As described earlier, the chapter does not aim to develop systematic comparisons between the nation-states, but to proffer a cross-cultural analysis of "analogical incidents" (Lappalainen, Lahelma, and Mietola 2015, pp. 845-846). From a cross- 


\section{Helakorpi}

cultural analysis perspective, the interviewees share positions as individuals implementing national policies.

I initially analysed the interviews by identifying how the provision of knowledge about Roma and Travellers was discussed. I organised the data into two categories: what type of content the interviewees describe (what is this knowledge?), and what they aim to achieve by providing this type of knowledge (what does the knowledge do?). My emphasis was to find possible patterns in their reasoning and choices of topics, and this was done through intensive reading of the data, together with theoretical literature (Koski 2011; Coffey and Atkinson 1996). Finally, I identified that the discussions about the provision of knowledge concentrated on two main topics: the racialisation of Roma and Travellers, and the silence around a Roma and Traveller presence in the nation-states. That these two topics paradoxically contradict each other resulted in inevitable ambivalences and tensions that emerged throughout the process of articulating one's position.

\section{Racialisation}

The ways in which the interviewees made sense of their practice of providing knowledge about Roma and Travellers point towards the persistence and frequency of what I name as the processes of racialisation of Roma and Travellers in schools. Racialisation refers to the ways race, as a social and political category, is signified and established. Processes of racialisation construct and stabilise categories of Other, connecting certain differences to these categories. Typically, the attributes associated with the Other contain negative signifiers, and the Other is represented as inadequate or threatening. The perceived differences between "us" and the Other begin to seem natural and essential, thus enabling racialised power relations to become legitimised (Mulinari et al. 2009; Lentin 2008). I argue that while my interviewees try to negotiate within these discourses and find ways to use knowledge about Roma and Travellers to disturb the processes of racialisation, the practice of providing knowledge about Roma and Travellers cannot totally avoid contributing to the very same racialising discourses that they aim to tackle.

In all the contexts studied, the interviewees explained that they aim to challenge dominant cultural perceptions concerning Roma and Travellers. One such perception was that Roma would want to remain outside societal or education structures. In the next excerpt, a Swedish interviewee describes how school personnel should know more about the willingness of Roma to educate themselves, gain employment, and be part of society:

I: So when you said that school personnel should know about Roma culture, what kinds of things should they know?

R: It has never been so that one needs to be educated. One needs a job. And that has to do with the fact that one did not have a right to work. And this is what so many Roma have gone through. Education. They have not 
had the right to go to school. They have not had the right to a residence, to settle. They have been forced to travel from municipality to municipality. One could live only three weeks in the same place. And Roma culture, this has got into our culture. That we did not have a permission to go to school. And that is what is important. That the school personnel must get to know that. And it is not just that one does not want to go to school. That we don't prioritise education. That we don't want to have a job. That we want to stay out of society. That is not true. We will also be in society and we will also work. And that is what I tell the teachers.

In the above extract, the interviewee reacts to a racialising narrative about Roma: it is widely assumed that Roma culture conflicts with education. The same argumentation was also used when the states' assimilation measures were justified in earlier times (e.g. Pulma 2006). Although this conception has been criticised for not having empirical backing (Brüggemann 2014; Rodell Olgaç 2006, 2013; Matache 2017), the perception is still invoked, repeatedly, in development projects and academic research all over Europe. Through this narrative, Roma are racialised by attaching negative signifiers to them, and they become represented as threats to society. Despite the apparent diversity of groups and histories within the Swedish national minority Roma group, the Swedish interviewee reacts to the racialising narrative by representing a homogenising description of the Swedish Roma and posits themselves as representing all of "us". I understood this as a strategy which draws upon the Swedish discourse around the united group of national minority Roma. Although it is problematic, Elisabeth Eide (2010) has demonstrated how essentialising can be a strategy for individuals positioned as representatives of a minority to get heard; in this case, the interviewee turns our gaze towards the atrocities committed by the Swedish state and challenges the narrative of problematic Roma culture.

In the next excerpt from Norway, a Norwegian Roma interviewee likewise reacts to racialising narratives about Roma:

R: Most important for the Roma today is to highlight their culture. And to show that you are a people in Norway. A minority. Then there are many unique cultural traditions. [indistinct on the tape]. Very important that it is highlighted today in Norway because the Norwegians, I mean the nonRoma [Norwegians], they don't know what we do and what we stand for. And always when they ... hear for instance that gypsies (zigenare), which we are often called, so, it is that we are bad people. That we steal, we are criminals. That we are not stable. And that is not true. [...] There is [criminality] also among Roma. Those who steal and who are criminals. But they are not many. They are not many. And that is what is regrettable. That does not come up. That in Norway people know more about us just the negative but not the positive. And that is what I feel we should highlight. 


\section{Helakorpi}

The interviewee describes how criminality is associated with Norwegian Roma, and thus Roma are positioned as threats to Norwegian society (see also Rosvoll and Bielenberg 2012). In their account, the Norwegian interviewee does not totally reject the notion of "bad Roma", but emphasises that Roma should actively represent the positive sides of themselves. I have argued elsewhere that similar discursive patterns about representing positive sides of Roma occur in Finnish schools (Helakorpi, Lappalainen, and Sahlström 2019). This notion of making positive representations instead of negative ones demonstrates the underlying assumption in the discourse about the provision of knowledge: that minoritised groups are responsible for the perceptions carried by people in privileged positions. This becomes even more apparent in the next excerpt with a Swedish interviewee, who also responds to racialising narratives about Roma:

R: That we are a heterogeneous group. That is very important. Because people don't have any knowledge about that. But they think that a Rom is a Rom. But it is not accurate. We are very different. And we have very different identities. We have different beliefs. So that is a very big difference in us. Certain girls cannot use trousers for instance. Among some groups. Other Finnish groups just have these [indistinct on the tape] long skirts. So I mean there we don't have that much in common with that group, like we don't speak the same language at all. We don't have the same religion. We don't have the same traditions. They are like behind. They are very ... they have not developed their [indistinct on the tape] as much. They keep rock solid this culture and that, while others think ... no, it is like medieval, it is Stone Age, like come on. So that is what I try to bring up. That we are very different. So that they often meet the groups which have problems. The good ones are not visible because they merge in. So the image they have about us are these, you know, prejudices. It is this image they have, and that is what I try to eliminate in some way. That you can't just believe that. You need to believe that there are thousands of others who are just like everyone else. Like goes to work. Have hobbies. Go out and do all the other stuff that other people do. Unfortunately you are always unlucky [indistinct on the tape] and see only the bad and worst there are. Peoples can actually have a bad reputation. And that is what we have. We have been labelled. So that is what I try to open, their eyes and ears. So I hope it sticks with them. And often when people go to it [indistinct on the tape] so they say like "I have a neighbour who parties all night". Yeah, well then you are unlucky, and you live in that area just next to that neighbour. I also have a neighbour who parties all night. They go to sleep at ten o'clock. So that, or another "yeah but there was a boy who stole my daughter's bike" or. So those kinds of stories I get to hear. 
Yet again, an interviewee responds to racialising narratives of Swedish Roma. In those narratives, Swedish Roma are depicted as behaving badly, stealing, and having problems. The interviewee tackles this by emphasising the heterogeneity of Roma. They list topics such as beliefs, clothing, identity, and traditions that are typically employed to establish the difference of the Other, using these to highlight the heterogeneity of Swedish Roma. However, like the Norwegian interviewee or the Finnish interviewees, this Swedish interviewee does not reject the notion of "bad Roma". On the contrary, the interviewee ambiguously connects negative signifiers such as backwardness and problems to one Roma group. Thus, a paradox can be identified in this interview: while they want to resist racialising descriptions of Roma, they end up making a racialising description of one of the Swedish Roma groups. Although they criticise the way people depend on prejudices, they constitute a narrative of other Roma fitting these prejudiced descriptions.

While most of the interviewees described how they want to counter and change the racialising narratives about Roma, one of the interviewees in Sweden had a different approach: instead of countering the racialisation of Roma, or reinforcing descriptions concerning Roma, their lectures focused on the exclusive mechanisms and normativities of schools in general. Thus, the interviewee turned the gaze from Roma towards the school system. They, however, pointed out that when planning and delivering these types of lectures, one needs to be careful not to make people feel guilty. This indicates the responsibility the interviewees are carrying: it is their responsibility to both change narratives, and do so in a manner that is comfortable for school communities.

I argue that within the sense-making of my interviewees, the limitations and problems of the discursive terrain around "the provision of knowledge about minoritised groups" emerges. I have identified that across all the studied contexts, the interviewees want to react to processes of racialisation of Roma and Travellers in school. However, when aiming to counter the racialising narratives with an opposing narrative, the interviewees often end up employing homogenising descriptions. On the other hand, when trying to disturb racialising narratives by emphasising the heterogeneity of Roma, interviewees do not fully reject the racialising notions, but accept them through reproducing an ambiguous description of "the bad Roma" who are responsible for the racialising notions people possess. The underlying assumption in the provision of knowledge about Roma and Travellers seems to be that Roma and Travellers are responsible for the perceptions people carry: Roma and Travellers need to replace the current narratives with new ones, and/or take the blame by (re)producing an ambiguous category of "the bad Roma" from which the racialising notions originate. Either way, non-Roma/Travellers are not held liable for the persistent reproduction of racialising narratives about Roma and Travellers, or for changing those narratives. 


\section{Silence about Roma and Travellers in the nation-states}

R: And to learn about us. Because they don't know anything about us. They believe we were people who lived 300 years ago in an adventure book. But we do exist today. So we try to teach them about our culture and history, and have an understanding about the fact that we are here, and who we are.

In the excerpt above, a Norwegian Traveller interviewee describes arriving at the startling conclusion that their very existence is absented from dominant understandings of Norwegian society; there is thus an urgent need for increasing the visibility of Travellers within Norwegian education: "so we try to teach them ... that we are here". In fact, according to the national curricula in all these countries, pupils should learn about national minorities during basic education (i.e. comprehensive school; FNBE 2014; Skolverket 2011; RMERCA). However, Finnish, Swedish, and Norwegian reports have shown that in textbooks - which often drive teaching practices more than national curricula (Pudas 2011) - minoritised groups are hardly visible (Midtbøen, Orupabo, and Røthing 2014; Tainio and Teräs 2010; Institutet för språk och folkminne 2016; SVT nyheter 2016). However yet again, the question arises of how national minorities should be visible. My interviewees described contents such as history, culture, and crafts, and my analysis suggests that the narrative of the relationship between the nation-state and Roma and/or Travellers has a significant role.

Many Swedish interviewees described the relationship between Roma and the Swedish nation-state through historical atrocities and current discrimination, which can be understood as an oppositional and antagonistic positioning. Furthermore, in these descriptions, the Swedish state became represented as unequal and oppressive. Through these types of narratives, the interviewees wanted to build a basis for understanding the present-day position of, and structural discrimination against, Roma in Sweden:

R: Then, when we tell about the history, we go to the Second World War, we go into Josef Mengele, what he, what Hitler did with Roma. How it was in the 1970s. How the change took place. And then we come to the fact that today they are still an oppressed group. Even today, 2015. They don't have their rights. And I mean we live in a Swedish society. It should be different. It is not so today.

The interviewee mentions the persecution of, and medical experiments on, Roma during the Second World War in Europe. Although hundreds of thousands of Roma were murdered in Nazi extermination camps and subjected to inhumane medical experiments (Brearley 2001), the persecution of Roma during the Second World War is still today often ignored (World Roma Organisation 2017; Pulma 2006). The interviewee uses history to draw connections to present-day discrimination in Sweden. 
In Finland, the interviewees had a very different perspective when describing the Roma presence, and the relationship between Roma and the Finnish nation-state. The Finnish interviewees seemed to approach history from a lighter and happier perspective than the Swedish interviewees: they marginalised the relationship of Roma and the Finnish state by concentrating on cultural artefacts and micro-histories of individual Roma. However, as the next excerpt with a Finnish interviewee demonstrates, effacing the violent role of the nation-state was strategic, and served a greater purpose:

R: And of course about history. If one does not know history it is difficult to understand the present

I: $\mathrm{Mmm}$

R: So, in the 1600 s there were Roma coming to Finland. Of course there are also all these regrettable [issues] and these. I usually don't want to bring these up because it kind of undermines the issue. People stay and chew over the wrong [issue], and they even freeze. The truth is that in history, there are these hard issues, which also many times cause the fears that Roma have

I: Right

R: So it is not, for instance, always futile [to fear]. It has been passed on in a certain way, it has been told [to new Roma generations] what has happened

I: Mmm, right

$\mathrm{R}$ : And the fear that children are taken away.

When presenting me with materials concerning Roma, the interviewee introduced a film about a Roma pupil's day at school, descriptions of Roma culture, as well as interviews with Romani elders and youngsters about their educational and employment careers. In the aforementioned excerpt, the interviewee commented on history, noting that some of the fears Roma have are reflective of the historically abusive policies of the state. In fact, the removal of Roma children from their families, and their placement in Roma children's homes, constituted the core of Finnish Roma policies until the turn of the 1970s (Pulma 2006; Friman-Korpela 2014). However, the interviewee decided not to concentrate on "difficult issues", because it was felt that people are unable to handle them. I understand this as my interviewee's strategy: previous studies show that working with diversity in institutions is often better executed in "happier language", because emphasising issues such as racism or historical misconduct may result in the majority's lack of interest in co-operating (Ahmed 2012, p. 175). According to my reading, in Finnish schools, there is little room to present the historical mistreatment of Roma.

The same kind of strategy is visible in the next excerpt, likewise from Finland, where an interviewee describes a Roma history workshop organised for schools. The interviewee had also arranged workshops focusing on music, crafts, and customs: 
R: The history [workshop] has been a bit like this time machine thing, where there has been a PowerPoint about how at first, people travelled with sleighs, and now people move with cars.

I: Yeah [laughs]

R: [Laughs]

The idea of a time machine gives the workshop an entertaining and fun tone. Furthermore, the story of the changing means of transportation positions Roma as part of a common history about changing technology, and the relationship between the nation-state and Roma becomes blurred. Within these narratives of a Roma presence in Finland, the Finnish interviewees may want to resist a narrative of conflict between the Roma and the nation-state. Connecting Roma history to common themes, such as technical developments, ties Roma to the shared history of Finns. Where the Swedish interviewees emphasise the friction between Roma and the nation-state was in part due to the atrocities committed by the state, the Finnish interviewees emphasise the shared nation-space, and the individual stories and resources of Roma.

In the next excerpt from Norway, a Traveller interviewee has yet another kind of approach where, through role play, they bind together both happy practices of multiculturalism, and narratives about the oppressive state:

R: [...] There [in role play] they can live a little bit like in our situation. So that it is a little bit like a play [acting], music and songs, and a little bit like playing and make it kind of lively there.

I: Very interesting

R: [...] so, that they do in schools [...] when they teach the youth. Live our life and get dressed like Travellers. So, they dress like us and live like our life. So then they encounter resistance from society. So, they learn to see it from our [indistinct in the tape] [...] so the people who have been a bit negative, when they begin, they become totally the opposite. Thus, they understand. "Oh, is it like this?" Yes. Then they understand it, when they get to live it a little themselves. Thus, it does something to them. [...].

In the excerpt, cultural celebration via music, songs, and clothing is used to discuss discrimination. The Norwegian state is described as oppressive, and at the same time a representation of Traveller life is displayed through artefacts such as clothes. Celebration and the display of cultural artefacts - as the Finnish Roma and Norwegian Traveller interviewees describe - is a fairly typical and recognised way of including knowledge about minoritised groups in the official education system (e.g. Gorski 2016). Thus, schools may be receptive to this way of including Roma and Travellers within educational content. The emphasis on crafts, music, careers, and travelling by different vehicles may aim to emphasise the "capital" of Roma and Travellers, as well as their agency, and how they can be considered resources within the countries. However, in contrast to the Finnish interviewees, the Norwegian 
Traveller interviewees use "happy" multiculturalism to also narrate the oppressiveness of the Norwegian state.

Kumashiro (2002, p. 39) claims that for knowledge about minoritised groups to be transformative, it is important to aim to change the underlying story of the nation-state. According to my interview analysis, the narrative of the relationship between Roma, Travellers, and the nation-state is likewise important-however, the possibilities to narrate this are contextually bound. The Swedish Roma and Norwegian Traveller interviewees emphasise the oppressive nature of the Swedish and Norwegian nation-states, and the distinctiveness of the historical experience of the groups, whereas the Finnish Roma bring forth the shared nation-space and minimise historical atrocities. I connect these differences between the countries to current state-level Roma politics and public discourses. As the only Nordic country to do so, the Norwegian government apologised to Travellers in 1998 and 2000 (NOU 2015; St. Meld. nr. 15, 2000-2001) and Roma in 2015 (government.no, 2015) for historical atrocities. In Sweden, a considerable issue in Roma politics has been the release of a white paper-The dark and unknown history: White Paper on abuses and the rights violations of Roma during the 1900s (Vitbok 2014) - which also resulted in the founding of a commission against antiziganism during 2014 to 2016 (SOU 2016). The white paper concentrates on abuses during the twentieth century, which was the time period emphasised by the Swedish interviewees, and the commission published and distributed a version of the white paper for pupils and teachers. Furthermore, in 2013, an illegal register about Roma kept by the police was revealed in Sweden. The register included thousands of Roma, from the already deceased to small children. The register received attention in Swedish society and made visible the current discrimination Roma face. While past and present discrimination against Roma and Travellers has been discussed in Swedish and Norwegian society, the Finnish state has never made an account of the abuse and persecution of Roma (see also Nordberg 2015). These differing public discourses may enable and constrain different narratives about the relationship between Roma, Travellers, and the nation-state in schools.

\section{Conclusions: Paradoxes, constraints, and possibilities in providing knowledge about minoritised groups}

In this chapter, I have conducted a cross-cultural analysis of the ways 18 individuals who identify as Roma or Traveller make sense of the practice of providing knowledge about Roma and Travellers in schools. According to my analysis, an underlying assumption in the practice is that Roma and Travellers are responsible for those narratives, perceptions, and practices people in privileged positions hold and reproduce. The analysis suggests the processes of racialisation of Roma and Travellers in schools is persistent and commonplace, which my interviewees aim to disturb with the provision of knowledge about Roma and Travellers. The interviewees moved between two strategies: 
1) emphasising the heterogeneity of Roma and Travellers, and 2) producing homogenising and essentialising counter-narratives related to the groups. However, neither of the strategies could totally avoid contributing to the very same racialising discourses the interviewees aimed to tackle: when emphasising the positive features and heterogeneity of the groups, an ambiguous category of "some bad Roma" occurred, and was held responsible for current racialising narratives. On the other hand, when challenging racialising narratives with counter-narratives, the interviewees often relied on homogenising and essentialising the groups, which in itself cannot challenge the logic of racialisation either. The underlying assumption in the practice seemed to be that non-Roma and non-Travellers were not accountable for the racialisation of Roma and Travellers in schools and societies, or for changing current racialising discourses.

Another observation in this chapter is that in providing knowledge about Roma and/or Travellers, the narration of the relationship between Roma/Travellers and the nation-state was significant. However, the analysis suggests that this narration is enabled and constrained by context: the differing ways the past and present are being discussed within nation-states is visible in the interviews. Furthermore, the interviewees not only narrated within the limits and possibilities of the public discourses, but also seemed to be sensitive about the school context, and its multicultural practices. In Sweden and Norway, there was space for describing the nation-states as historically and currently oppressive, whereas in Finland no such space seemed to exist.

As described from the outset, previous critical literature analysing the practice of providing knowledge about minoritised groups has emphasised the importance of analysing power within institutions (Gorski 2006; hooks 1994; Kumashiro 2002). One of my interviewees aimed to carry this out by giving lectures about the exclusive mechanisms and normativities present within school systems. However, when conducting these lectures, the interviewee noted the need to be careful not to make people feel guilty. The point raised brings forward yet again that the interviewees are bound by their contexts when developing their practices. This chapter demonstrates that school communities and policymakers should actively analyse power relations to tackle racialising processes within institutions, rather than merely waiting for minoritised groups to bear this responsibility. In addition, a serious rethinking of the narratives of the nation-states, and their historical and current role in injustice and racism, should be undertaken widely within societies and institutions; people in minoritised positions should not be left solely responsible for disturbing the current narratives. To conclude, the analysis of this chapter suggests that the policy measure of the provision of knowledge about minoritised groups should be expanded so that schools and institutions are held responsible for rethinking and re-narrating the nation and its institutions. 


\section{Notes}

1 This chapter has gone through an external blind review and was accepted by three reviewers. We thank the reviewers for their work with the chapter.

2 Internationally, the term "Roma" is often used as an umbrella term for all Roma groups, including Swedish Travellers (resande) and Norwegian Travellers (romanifolk/tatere). However, in the Nordic context, the term "Roma" is typically understood as excluding (especially the Norwegian) Travellers.

3 Today, racism against Roma groups is often referred to with the specific term "antigypsyism" (see e.g. antigypsyism.eu).

4 The numbers are estimates, as there are no statistics on ethnic grounds in these countries.

5 From one Swedish interview, there are only handwritten notes, since the interviewee asked me not to record.

\section{References}

Ahmed, S. (2012). On being included: Racism and diversity in institutional life. Durham, NC: Duke University Press.

Arbeids- og inkluderingsdepartementet (AoI). (2009). Action plan for improvement of the living conditions of Roma in Oslo. Retrieved from https://www. regjeringen.no/globalassets/upload/FAD/Vedlegg/SAMI/Nasjmin/Handlingspla n_rom_EN.pdf

antigypsyism.eu (2017). Reference paper [online]. Available at: http://antigypsyism.eu/? page_id=17 [Accessed 8 October 2018].

Brearley, M. (2001). 'The persecution of Gypsies in Europe'. American Behavioral Scientist, 45(4), pp. 588-599.

Brubaker, R. (1996). Nationalism reframed: Nationhood and the national question in the new Europe. Cambridge: Cambridge University Press.

Brüggemann, C. (2014). 'Romani culture and academic success: Arguments against the belief in a contradiction'. Intercultural Education, 25(6), pp. 439-452.

Bunescu, I. (2014). Roma in Europe. The politics of collective identity formation. London: Routledge.

CoE [Council of Europe]. (2012). Council of Europe Descriptive Glossary of terms relating to Roma issues. [pdf] Available at: http://a.cs.coe.int/team20/cahrom/docum ents/Glossary\%20Roma\%20EN\%20version\%2018\%20May\%202012.pdf [Accessed 8 October 2018].

Coffey, A. and Atkinson, P. (1996). Making sense of qualitative data: Complementary research strategies. Thousand Oaks: SAGE Publications.

Davies, B. (2004). 'Introduction: Poststructuralist lines of flight in Australia'. International Journal of Qualitative Studies in Education, 17(1), pp. 3-9.

Eide, E. (2010). 'Strategic essentialism and ethnification. Hand in glove?' Nordicom Review 31(2), pp. 63-78.

Engebrigtsen, A. I. (2015). 'Educating the Roma: The struggle for cultural autonomy in a seminomadic group in Norway'. Social Inclusion, 3(5), pp. 115-125. doi:10.17645/ si.v3i5.275

FNBE [Finnish National Board of Education]. (2014). Perusopetuksen opetussuunnitelman perusteet 2014. Opetushallitus. Määräykset ja ohjeet 2014:96. [pdf] Available at: http://www.oph.fi/download/163777_perusopetuksen_opetussuunnitelman_peru steet_2014.pdf [Accessed 8 October 2018]. 


\section{Helakorpi}

FRA [European Union Agency for Fundamental Rights]. (2018). A persisting concern: anti-Gypsyism as a barrier to Roma inclusion [pdf] Available at: http://fra. europa.eu/en/publication/2018/roma-inclusion [Accessed 8 October 2018].

Friman-Korpela, S. (2014). Romanipolitiikasta romanien politiikkaan. Poliittisen asialistan ja toimijakonseption muutos 1900-luvun jälkipuoliskon Suomessa. PhD. University of Jyväskylä.

Gorski, P. (2006). 'Complicity with conservatism: The de-politicizing of multicultural and intercultural education'. Intercultural Education, 17(2), pp. 163-177.

Gorski, P. (2016). 'Rethinking the role of "culture" in educational equity: From cultural competence to equity literacy'. Multicultural Perspectives, 18(4), pp. 221-226.

Government.no (2015). International Roma Day, 8 April 2015 [online] Available at: https://www.regjeringen.no/en/aktuelt/den-internasjonale-romdagen/id2404809/ [Accessed 8 October 2018].

Hancock, I. (1989). The pariah syndrome: An account of Gypsy slavery and persecution. Ann Arbor: Karoma.

Helakorpi, J., Lappalainen, S. and Mietola, R. (2018). 'Equality in the making? Roma and Traveller minority policies and basic education in three Nordic countries'. Scandinavian Journal of Educational Research, DOI: 10.1080/00313831.2018.1485735

Helakorpi, J., Lappalainen, S. and Sahlström, F. (2019). 'Becoming tolerable: Subject constitution of Roma mediators in Finnish schools'. Intercultural Education, 30(1), pp. 51-67, DOI: 10.1080/14675986.2018.1537671

hooks, b. (1994). Teaching to transgress. Education as the practice of freedom. New York: Routledge.

Insititutet för språk och folkminne (2016). Brister i undervisningen om de nationella minoriteterna och minoritetsspråken [online] Available at: http://www.sprakoch folkminnen.se/om-oss/nyheter-och-press/nyhetsarkiv/nyheter-2017/2017-05-24-bris ter-i-undervisningen-om-de-nationella-minoriteterna-och-minoritetsspraken.html [Accessed 8 October 2018].

Izsák, R. (2015). Comprehensive study of the human rights situation of Roma worldwide, with a particular focus on the phenomenon of anti-Gypsyism. Report to the Human Rights Council. Available at: https://www.ohchr.org/EN/HRBodies/HRC/ RegularSessions/.../A_HRC_29_24_E.doc

Junkala, P. and Tawah, S. (2009). Enemmän samanlaisia kuin erilaisia: Romanilasten ja nuorten hyvinvointi ja heidän oikeuksiensa toteutuminen Suomessa. Lapsiasiainvaltuutetun toimiston julkaisuja 2. Jyväskylä: Lapsiasiainvaltuutetun toimisto.

Keskinen, S., Alemanji, A. A., Himanen, M., Kivijärvi, A., Osazee, U., Pöyhölä, N., and Rousku, V. (2018). The stopped - ethnic profiling in Finland. Helsinki: Swedish School of Social Science.

Koski, L. (2011). Teksteistä teemoiksi, in Puusa, A., and Juuti, P. (eds.) Menetelmäviidakon raivaajat. Perusteita laadullisen tutkimuslähestymistavan valintaan. Vantaa: JTO, pp. 126-149.

Kumashiro, K. (2002). Troubling education. Queer activism and anti-oppressive pedagogy. New York \& London: Routledge Falmer.

Kymlicka, W. (2007). 'The internationalization of minority rights'. International Journal of Constitutional Law, 6(1), pp. 1-32.

Lahelma, E. (2005). 'School grades and other resources: The "failing boys" discourse revisited'. Nordic Journal of Women's Studies, 13(2), pp. 78-89.

Lappalainen, S., Lahelma, E., and Mietola, R. (2015). 'Problematizing evaluative categorisations: Collaborative and multisited interpretations of constructions of 
normality in Estonia and Finland', in P. Smeyers, D. Bridgges, N. C. Burbules, and M. Griffiths, (eds.) International handbook of interpretation in educational research. 1st ed. Dordrecht: Springer Science+Business Media, pp. 843-864.

Lentin, A. (2008). Racism. A beginner's guide. Oxford: Oneworld Publications.

Lindblad, S. and Popkewitz, T. S. (2003). 'Comparative ethnography: Fabricating the new millennium and its exclusions'. In Beach, D., Gordon, T., and E. Lahelma (eds.) Democratic education. Ethnographic challenges. 1st ed. London: Tufnell Press, pp. 10-14.

Matache, M. (2017). 'Biased elites, unfit policies: Reflections on the lacunae of Roma integration strategies'. European Review, 25(4), pp. 588-607.

Mattila, M. (2005). 'Sterilointipolitiikka ja romanit Suomessa vuosina 1950-1970', in Häkkinen, A., Pulma, P., and Tervonen, M. (eds.) Vieraat kulkijat—tutut talot: Näkökulmia etnisyyden ja köyhyyden historian Suomessa. 1st ed. Helsinki: SKS, pp. 407-410.

Midtbøen, A. H., Orupabo, J., Røthing, Å. (2014). Etniske og religiøse minoriteter i læremidler Lærer- og elevperspektiver. Rapport 2014: 11. Institutt for samfunnsforskning.

Montesino Parra, N. (2002). Zigenarfrågan: Intervention och romantik. PhD. Lunds Universitet.

MSAH (Ministry of Social Affairs and Health). (2009). The Proposal of the Working Group for a National Policy on Roma. Working group report. Helsinki: Ministry of Social Affairs and Health. [pdf] Available at: http://urn.fi/URN:ISBN: 978-952-00-2912-8 [Accessed: 8 October 2018].

MSAH (Ministry of Social Affairs and Health). (2016). Enhancing the visibility of the living conditions and status of the Roma in the Nordic countries [news item]. Retrieved from http://stm.fi/artikkeli/-/asset_publisher/romanienelinolot-ja-asema -pohjoismaissa-nakyvaksi?_101_INSTANCE_yr7QpNmlJmSj_languageId=en_US

Muižnieks, N. (2015). Report. Commissioner for Human Rights of the Council of Europe. Retrieved from http://www.humanrightseurope.org/2016/04/nils-muizniek s-human-rights-annual-report-2015/

Mulinari, D., Keskinen, S., Irni, S.ja Tuori, S. (2009). 'Introduction: Postcolonialism and the Nordic models of welfare and gender', in S. Keskinen, S. Tuori, S. Irni and D. Mulinari, (eds.) Complying with colonialism. Gender, race and ethnicity in the Nordic region. 1st ed. Farnham: Ashgate, pp. 1-18.

Non-discrimination ombudsman. (2014). Erilaisena arjessa-selvitys romanien syrjintäkokemuksista. [online] Helsinki: Vähemmistövaltuutettu. Available at: https:// www.syrjinta.fi/documents/10181/10850/52878_romaniselvitys_verkkoon+(1).pdf/ 584516fc-d3a7-4f88-8ecc-c8b2271ebf41 [Accessed 9 April 2019].

Nordberg, C. (2015). 'Dynamics of recognition: Minority ethnic access to transformative power in the Nordic welfare state', in Kraus, P. A., and Kivisto, P. (eds.), The challenge of minority integration. 1st ed. Berlin: De Gruyter Open, pp. 91-107.

NOU [Norges offentlige utredninger]. (2015). Assimilering og motstand Norsk politikk overfor taterne/romanifolket fra 1850 til i dag (NOU 2015:17). [pdf] Available at: https:// www.regjeringen.no/no/dokumenter/nou-2015-7/id2414316/ [Accessed 8 October 2018].

Pudas, A-K. (2011). 'Investigating possibilities to develop textbooks to implement global education in basic education instruction'. IARTEM e-Journal, 5(2), pp. 1-22.

Pulma, P. (2006). Suljetut ovet: Pohjoismaiden romanipolitiikka 1500-luvulta EUaikaan. Helsinki: Suomalaisen Kirjallisuuden Seura.

Rajala, S. and Blomerus, S. (2015). Katsaus aikuisten romanien koulutustaustoihin. (Reports 2015:8). Helsinki: Finnish National Board of Education. 
Rajala, S., Salonen, M., Blomerus, S., and Nissilä, L. (2011). Romanioppilaiden perusopetuksen tilannekatsaus 2010-2011 ja toimenpide-ehdotukset. (Reports 2011:26). Helsinki: National Board of Education.

Rekola, T. (2012). 'Romanien varhaisvaiheet Suomessa: 1600-luvulta 1800-luvun puoliväliin', in Pulma, P. (ed.), Suomen romanien historia. 1st ed., Helsinki: Suomen Kirjallisuuden Seura, pp. 18-83.

RMERCA [The Royal Ministry of Education, Research and Church Affairs]. Core curriculum for primary, secondary and adult education in Norway. [pdf] Available at: https://www.udir.no/globalassets/filer/lareplan/generell-del/core_curriculum_eng lish.pdf [Accessed 8 October 2018].

Rodell Olgaç, C. (2006). Den romska minoriteten i majoritetssamhällets skola: Från hot till möjlighet. PhD. Stockholm: HLS Förlag.

Rodell Olgaç, C. (2013). 'Education of Roma in Sweden: An interplay between policy and practice'. In Horneberg, S., and Brüggemann, C. (eds.), Die Bildungssituation von Roma in Europa. $1^{\text {st }}$ ed, Münster: Waxmann Verlag, pp. 197-213.

Rosvoll, M. and Bielenberg, N. 2012. Antisiganisme, stereotypier og diskriminering av rom. HL-senterets temahefte nr.14 [pdf] Available at: http://www.hlsenteret.no/publika sjoner/digitale-hefter/pdf/hl_temahefte_14_digital.pdf [Accessed 8 October 2018].

Skolverket. 2011. Curriculum for basic education, pre-school and the leisure-time centre 2011. Sweden [Revised 2016] [pdf] Available at: https://www.skolverket.se/om -skolverket/publikationer/visa-enskild-publikation?_xurl_=http $\% 3 \mathrm{~A} \% 2 \mathrm{~F} \% 2 \mathrm{Fwww} 5$. skolverket.se $\% 2$ Fwtpub $\% 2$ Fws $\% 2$ Fskolbok $\% 2$ Fwpubext $\% 2$ Ftrycksak $\% 2$ FRecord $\%$ $3 \mathrm{Fk} \% 3 \mathrm{D} 2575$ [Accessed 21 May 2018].

SOU. 2000: 20. Steriliseringsfrågan i Sverige 1935-1975 Historisk belysning - Kartläggning - Intervjuer [pdf] Available at: http://www.regeringen.se/49b6c6/contenta ssets/68b217b7f8e746a799536f3ad851c05e/steriliseringsfragan-i-sverige-1935-1975 [Accessed 8 October 2018].

SOU. 2010: 55. Romers rätt - en strategi för romer i Sverige. [pdf] Available at: http:// www.regeringen.se/rattsdokument/statens-offentliga-utredningar/2010/07/ sou-201055/ [Accessed 8 October 2018].

SOU. 2016: 44. Slutbetänkande av Kommissionen mot antiziganism, [pdf] Available at: http://www.regeringen.se/49e105/contentassets/b76e2b51299b42eba2c360c58f0754f7/ kraftsamling-mot-antiziganism-sou-201644 [Accessed 8 October 2018].

St. Meld. nr. 15, 2000-2001: 7 Det Kongelege kommunal- og regionaldepartement. Nasjonale minoritetar I Noreg - Om statleg politikk overfor jødar, kvener, rom, romanifolket og skogfinnar. [pdf] Available at: https://www.regjeringen.no/no/dokum enter/stmeld-nr-15-2000-2001-/id585195/ [Accessed 8 October 2018].

St. Pierre, E. (2000). 'Poststructural feminism in education: An overview'. Qualitative Studies in Education, 13(5), pp. 477-515.

St. Pierre, E. and Pillow, W. S. (2000). 'Introduction: inquiry among the ruins', in St. Pierre, E. and Pillow, W. (eds.), Working the ruins: Feminist poststructural theories and methods of education. 1st ed., New York: Routledge, pp. 1-25.

SVT nyheter. (2016). Minoriteter saknas i skolans historieböcker [online]. Available at: https://www.svt.se/nyheter/uutiset/svenska/minoriteter-saknas-i-skolans-histor iebocker [Accessed 8 October 2018].

Tainio, L. and Teräs, T. (2010). Sukupuolijäsennys perusopetuksen oppikirjoissa. Raportit ja selvitykset 2010:8. Helsinki: Opetushallitus.

Tervonen, M. (2012). "Gypsies", "travellers" and "peasants": A study on ethnic boundary drawing in Finland and Sweden, c.1860-1925. PhD. HEC Theses. 
van Baar, H. (2012). 'Socio-economic mobility and neo-liberal governmentality in post-socialist Europe: Activation and dehumanisation of the Roma'. Journal of Ethnic and Minority Studies, 38(8), pp. 1289-1304.

Vermeersch, P. (2006). The Romani movement: Minority politics and ethnic mobilization in contemporary Central Europe. New York: Berghahn Books.

Vitbok. 2014. Den mörka och okända historien. Vitbok om övergrepp och kränkningar av romer under 1900-talet. Ds 2014: 8. [pdf] Available at: http://www.regeringen. se/49baf8/contentassets/eaae9da200174a5faab2c8cd797936f1/den-morka-och-oka nda-historien - vitbok-om-overgrepp-och-krankningar-av-romer-under-1900-ta let-ds-20148 [Accessed: 8 October 2018].

Wiklander, L. (2015). 'Resandefolket och svensk minoritetspolitik: 1990-talets paradigmskifte'. Historisk tidskrift (Sweden), 135(4), pp. 622-648.

World Roma Organisation. (2017). Press release [online]. Available at: http://www. worldromaorganization.org/index.php/en/component/content/article/35-vazno/ 190-statement-of-wro-president-regarding-2nd-august-roma-holocaust-remembra nce-day [Accessed: 8 October 2018]. 